\title{
Mycosis Fungoides and Sezary Syndrome B2 TNM Finding v8
}

National Cancer Institute

\section{Source}

National Cancer Institute. Mycosis Fungoides and Sezary Syndrome B2 TNM Finding v8.

NCl Thesaurus. Code C141329.

High blood tumor burden: 1,000 per microliter or more Sezary cells with positive clone.

Note 1: for blood, Sezary cells are defined as lymphocytes with hyperconvoluted

cerebriform nuclei. If Sezary cells cannot be used to determine tumor burden for B2,

then one of the following modified ISCL criteria along with a positive clonal

rearrangement of the TCR may be used instead: (1) expanded CD4+ or CD3+ cells with

CD4/CD8 ratio of 10 or more, (2) expanded CD4+ cells with abnormal immunophenotype including loss of CD7 or CD26. Note 2: A T-cell clone is defined by PCR or Southern blot analysis of the T-cell receptor gene. (from AJCC 8th Ed.) 